\title{
Mulighetsrom i møte mellom inkludering og estetisk tilnærming til læring i grunnskolen
}

\author{
Audun Mollan Kristoffersen \\ Trondheim kommune og NTNU Norges-teknisk naturvitenskapelige universitet
}

\begin{abstract}
Sammendrag
Denne artikkelen undersøker hvilke muligheter innenfor inkludering og estetisk tilnærming til læring som kan skapes når nasjonale og internasjonale styringsdokumenter for skolen leses på tvers og underbygges av eksisterende fag og forskningsteori. Gjennom en kreativ refleksiv analyse som plasserer seg kunnskapsteoretisk under performativ forskning, skapes ulike mulighetsrom mellom inkludering og estetisk tilnærming til læring. Disse mulighetsrommene er: fredskultur, kreativitet, kulturell bevissthet, følelsesmessig engasjement, utvikling og likeverdighet. Med fag og forskningsteori som velges og leses ut fra sosiale dimensjoner og performativ tenkning, bygges mulighetsrommene videre ut med områder. Deretter kobles de utbygde mulighetsrommene opp mot en pedagogisk og didaktisk sammenheng. Til slutt løfter artikkelen frem hvilke nye muligheter en tenkning om inkludering og estetisk tilnærming til læring kan ha, for gradvis å skape et nytt skolerom for alle elevene i skolen.
\end{abstract}

Nøkkelord: Inkludering; estetisk tilncerming til laring; mulighetsrom; performativ forskning; kreativ refleksiv litteraturstudie

Mottatt: Oktober, 2019; Antatt: April, 2020; Publisert: Juni, 2020

\begin{abstract}
The educational potential at the intersection of inclusion and aesthetic approaches to learning in primary school

This article focuses on the intersection of inclusion and aesthetic approaches to learning. The author examines the educational potential that can be created through reading selected policy papers and existing research through one another. The research question posed is "What educational potential can be created in the encounter between inclusion and aesthetic approaches to learning, through reading selected policy papers and existing research through one another?”

The article is positioned within a performative research paradigm. The author uses a creative reflexive approach inspired by Alfonso Montuori (2005), which pushes the literature review into
\end{abstract}

^Korrespondanse: Audun M. Kristoffersen, e-post: audun.m.kristoffersen@ntnu.no

(C) 2020 A. M. Kristoffersen. This is an Open Access article distributed under the terms of the Creative Commons Attribution 4.0 International License (https://creativecommons.org/licenses/by-nc/4.0/), allowing third parties to copy and redistribute the material in any medium or format and to remix, transform, and build upon the material for any purpose, even commercially, provided the original work is properly cited and states its license.

Citation: A. M. Kristoffersen. «Mulighetsrom i møte mellom inkludering og estetisk tilncerming til laring $i$ grunnskolen».

fournal for Research in Arts and Sports Education, Vol. 4(1), 2020, pp. 52-75. http://dx.doi.org/10.23865/jased.v4.1956 
an act of creating something new, in this case potential for inclusion through aesthetic approaches to learning. Possibilities for the teacher's educational work in the encounter between inclusion and aesthetic approaches to learning are, in this article, created through the articulation of the following concepts at the cross point between inclusion and aesthetic approaches: Peace culture, emotional engagement, creativity, equality, cultural consciousness and development. These potential are further opened and discussed with the help of existing research literature.

Keywords: Inclusion; aesthetic approaches to learning; educational potential; performative research; creative reflexive literature review

\section{Pedagogiske øyeblikk - bakgrunn, hensikt og forskningsspørsmål}

«Hvor er grupperommet?». Spørsmålet kom fra en elev for noen år siden. Han skulle starte opp i en av gruppene jeg hadde ansvaret for. Det var skolestart, og jeg skulle være kontaktlærer og spesialpedagog for eleven. Eleven hadde tidligere hatt voksendekning, og han hadde vært mye for seg selv sammen med en voksen på et grupperom. Grupperommet var den skoleverdenen han kjente best, og nå ved oppstarten til en ny skole ble han usikker. Kanskje skjønte han at han nå skulle være en del av en gruppe? At han ikke skulle være på grupperommet? Som lærer ble jeg et øyeblikk fylt med undring. Undring fordi det er trist å se hva skoleerfaringer kan giøre, som for denne eleven, som søker seg til et grupperom for å oppleve en trygg skolehverdag. Uavhengig av skolens gode intensjoner hadde vi som skole tapt i det øyeblikket, tenkte jeg. I ettertid har dette øyeblikket gitt meg flere tanker. Tanker om det som kan kalles et felles skolerom som er trygt for alle, og at det manglet for denne eleven. Og at han i fravær av erfaringer av et trygt skolerom søkte seg til et isolert grupperom.

Som utdannet allmennlærer med fordypning i drama/teater, med master i spesialpedagogikk og med mange års erfaring som lærer i grunnskolen, har jeg ofte hatt en kreativ og leken tilnærming til læring. Gjennom bakgrunn fra drama/teater og spesialpedagogikk er jeg opptatt av estetisk tilnerming til laring i ulike inkluderende kontekster. For meg er det interessant å se at dette området ofte synes å være utelatt i debatten om skole og inkludering. I litteratur om estetiske læringsprosesser (Hohr, 2009, 2013) skrives det at dette området ofte faller «under offentlighetens radar» (Sæbø, Eriksson \& Allern, 2017, s. 18). Gjennom å falle «under offentlighetens rader» blir den estetiske inngangen til læring lite ivaretatt i skolerommet i praksis, og inngår mer som «krydder» ved store anledninger. Inkludering er ikke marginalisert på samme måte som det estetiske i skolen; det inngår oftere i den offentlige debatten. Men det er når inkludering $i k k e$ fungerer at temaet løftes fram i det offentlige. Inkludering som fungerer forsvinner også ofte under «offentlighetens radar». Det er for meg et tankekors at inkludering og estetisk tilnærming til læring blir viet lite oppmerksomhet, og da særlig i kombinasjon med hverandre, siden det er min forforståelse at disse to kan forsterke hverandre positivt.

Det er dette denne artikkelen skal handle om: inkludering og estetisk tilnærming til læring. I artikkelen er jeg interessert i hvilke muligheter som kan leses ut av nasjonale 


\section{A. M. Kristoffersen}

og internasjonale politiske styringsdokument som er relevante for skolen, samt muligheter som finnes i eksisterende fagteori innenfor inkludering og estetisk tilnærming til læring. Jeg er interessert $\mathrm{i}$ å se på hvilket mulighetsrom som kan skapes mellom inkludering og estetisk tilnærming til læring. Hvilket mulighetsrom kan koblingen mellom inkludering og estetikk gi i ulike læringskontekster? Forskningsspørsmålet som jeg ledes av i denne artikkelen er: Hvilke pedagogiske og didaktiske mulighetsrom kan skapes $i$ møte mellom inkludering og estetisk tilncerming til laring gjennom à studere utvalgte styringsdokumenter som har relevans for skolen og eksisterende fag-og forskningsteori?

Artikkelens intensjon er å undersøke hvilke muligheter eller mulighetsrom som ligger i det som omtales som skolerommet. Mulighetsrom er det virksomme rommet som blir til på læringsarenanen skapt av av læreren i spennet mellom det som styrer læreren og den friheten som læreren har. Jeg kommer tilbake til en definisjon av mulighetsrom litt senere $\mathrm{i}$ artikkelen. Det vil bli gitt argumenter for hvorfor det er viktig å ta i bruk mulighetene som ligger i et skolerom for alle. Pedagogikk er her forstått som undervisningens overordnede mål om å sikre størst mulig aktiv og intelligent deltagelse i retningen mot et bedre samfunn (Dewey, 2008, s. 29). Didaktikk forstås som utøvelse av undervisningskunsten (Bø \& Helle, 2007, s. 44). Idealet i didaktikk er hvordan undervisningskunsten praktisk kan komme til uttrykk.

\section{Oppbygning}

Gjennom en kreativ refleksiv analyse (Montuori, 2005) vil jeg ta utgangspunkt i ulike internasjonale og nasjonale styringsdokument, lovverk, forskning og fagteori innenfor temaene inkludering og estetisk tilnærming til læring. I min analyse vil jeg se etter hvilke mulighetsrom som kan skapes i møte mellom inkludering og estetisk tilnærming til læring. En av hensiktene med artikkelen er å bidra innenfor et marginalisert område i forskning om inkluderende fellesskap i skolen. En tidligere lærer av meg innen spesialpedagogikk brukte å si at inkludering handlet om «hvordan man kunne tenke en tanke annerledes» når man møter på utfordringer i praksis. Det fordrer ofte kreativitet, og her vil refleksjoner knyttet til relasjonen mellom styringsdokumenter og teori om inkludering og estetisk tilnærming til læring sammenkobles.

Først vil jeg kort beskrive tre sentrale begreper som artikkelen dreier seg rundt: inkludering, estetisk tilnærming til læring og mulighetsrom. Deretter vil jeg gjøre rede for metodologiske perspektiver. Jeg vil så analysere noen valgte nasjonale og internasjonale styringsdokumenter, og se etter mulighetsrom som kan skapes mellom inkludering og estetisk tilnærming til læring. Der jeg kan skape sammenfallende mulighetsrom vil jeg diskutere disse opp mot eksisterende forskningslitteratur og fagteori innenfor inkludering og estetisk tilnærming til læring. Jeg vil også drøfte hva og hvordan mulighetsrom mellom styringsdokumenter og fagteori kan bidra med i lærerens pedagogiske og didaktiske handlinger i skolerommet. 


\section{Sentrale begreper}

Inkludering

Forståelsen av inkludering i utdanning er definert på ulike måter (Nes, 2018, s. 83).

I denne artikkelen er følgende definisjon av inkludering sentral:

Inkludering kan sies å innebære en tenkemåte og dermed en handlemåte der inkludering er et veiledende prinsipp for det pedagogiske arbeidet, og der et høyere mål er å bidra til et mer inkluderende og bærekraftig samfunn der mulighet til å oppleve mestring sammen med andre er sentralt. (Nordahl, 2018, s. 27)

I lys av ovenstående sitat kan inkludering forstås som en pedagogisk tenke- og handlemåte som bidrar til å se etter muligheter til å skape opplevelse av mestring og fellesskap både individuelt og $\mathrm{i}$ gruppe.

\section{Estetisk tilnærming til læring}

En kortfattet og innledende definisjon av estetisk tilnærming til læring er å se den som meningsskaping gjennom arbeid med formuttrykk. «Sansebaserte innganger til læring kalles ofte estetiske fordi de har et opplevelsespotensial", skriver Anna-Lena Østern (2010, s. 184). John Dewey (1934/1980) på sin side skriver at formskapende aktiviteter er en erkjennelsesform, som skaper en relasjon mellom individet og verden. I den formskapende aktiviteten oppstår et sansenærvær som kan forstås som opplevelse. «I opplevelsen kommer vi til oss selv som bevisste relasjoner til hverandre og til verden som sådan," skriver Hansjörg Hohr (2013, s. 232). En estetisk tilnærming til læring kan bidra til transformasjon der ny erkjennelse, ny mening og nye handlinger blir skapt giennom forholdet mellom opplevelse og læring (Dewey, 1934/1980, s. 63). En slik forståelse av estetisk tilnærming til læring er sentral i denne artikkelen.

\section{Mulighetsrom}

I artikkelen forsøker jeg å skape mulighetsrom som kan oppstå i mellomrommet mellom estetisk tilnærming til læring og inkludering. Anniken Randers-Pehrson (2016) har skrevet en doktorgradsavhandling med en klar fagdidaktisk forankring innenfor grunnskolefaget kunst og håndverk. En målsetting i hennes studie er å utvikle kunnskap om hva som skjer i møtet mellom elever, lærer og faglig innhold. Hun undersøker hvordan mønstre og måter å gjøre ting på i fagets undervisning (kunst og håndverk) påvirker undervisningens læringsrom. Hun undersøker blant annet sammenhengen mellom etablerte mønstre og praksier i skolen med hva som er mulig å giøre. Til dette anvendes begrepet mulighetsrom, og hun definerer det slik: «Mulighetsrommet kan forstås både som intensjonalt og som et virksomt rom som produseres med utgangspunkt i den kollektive læringsarenaen, slik den settes sammen av læreren» (Randers-Pehrson, 2016, s. 266). Et funn i hennes oppgave er at måten læreren initierer, presenterer og formidler en oppgave på, har konsekvenser for deltakelsen. 


\section{A. M. Kristoffersen}

Mulighetsrommet indikerer hva som er mulig og ikke mulig for elevenes deltagelse i arbeidet. Funnene viser at måten læreren aktiviserer innholdet på, i et spenn mellom frihet og styring, har konsekvenser for elevenes deltagelse i undervisningen. (Randers-Pehrson, 2016, s. 267)

Med utgangspunkt i styringsdokumenter, og inspirert av perspektivet til RandersPehrson, skal jeg se på hvilke muligheter som kan ligge $\mathrm{i}$ å forene inkludering og estetisk tilnærming til læring for elevene i undervisningen.

Begrepene inkludering, estetisk tilnærming til læring og mulighetsrom har alle transformative aspekter ved seg, og innenfor artikkelens ramme kommer jeg til å fokusere på muligheter, mer enn hvor begrensningene ligger. Inkludering og estetisk tilnærming til læring vektlegger begge relasjonelle og sosiale aspekter, noe som også kommer til å styre mitt blikk når jeg leter etter å skape mulighetsrom.

\section{Oppsummerende}

En oppsummering av hvordan begrepene operasjonaliseres i denne studien kan skrives slik: Inkludering handler om hvordan man kan - og må - tenke mestring og muligheter i pedagogisk arbeid på en ny måte. Det estetiske handler om hvordan meningsskaping skjer gjennom opplevelse og formgivning, og mulighetsrom handler om anledningene som kommer til syne mellom det som er intensjonalt og virksomt. Begrepene inkludering og estetisk tilnærming til læring, samt mulighetsrom midt imellom det intensjonale og virksomme, virker på det jeg kaller skolerommet, og fungerer som sentrale omdreiningspunkt i denne artikkelen.

\section{Kunnskapsteoretisk posisjonering og analysemetode}

Artikkelen plasserer seg kunnskapsteoretisk under performativ forskning (Østern, Dahl, Strømme, Petersen, Østern \& Selander, 2019). Med det mener jeg at jeg fokuserer på at noe nytt blir til i møte mellom inkludering og estetisk tilnærming til læring. Jeg lar styringsdokumenter og fag- og forskningsteori fra inkludering og estetisk tilnærming til læring fungere performativt på hverandre. Jeg ser etter hvilke mulighetsrom som oppstår i møte mellom estetisk tilnærming til læring og inkludering. Idealet er en kunstners søkende muligheter i starten av en kunstprosess. Her finner jeg støtte i Kenneth J. Gergen og Mary Gergen (2018) som beskriver at det er tre grunnleggende kjennetegn ved forskning som bedrives innenfor det performative paradigmet:

1) Performativ forskning er for andre, det er til for et "publikum».

2) Performativ forskning prøver ikke bare å reflektere over forandringer som allerede er gjort, den kommer direkte med forandringer.

3) Fokuset i performativ forskning er på handlingene som blir til i forskerens søken. (Gergen \& Gergen, 2018, s. 54) 
Som analysemetode benytter jeg en kreativ refleksiv tilnærming til styringsdokumenter, og til valgt litteratur. Alfonso Montuori (2005) tar til orde for at litteraturgjennomganger kan være en kreativ prosess, der fortolkeren er en aktiv part gjennom meningsdanning i kommunikasjon med den litteraturen vedkommende møter. Dette er også i tråd med en overordnet performativ kunnskapsteoretisk tilnærming.

A literature review can be framed as a creative process, in which the knower is an active participant constructing an interpretation of the community and its discourse, rather than a mere bystander who attempts to reproduce as best she or he can, the relevant authors and work. (Montuori, 2005, s. 375)

Montuori understreker at refleksjon omkring litteratur bygger på personlige erfaringer. Det åpner for å kunne se etter tomrom eller muligheter i møte med litteraturen. I skjæringspunktet mellom pedagogikk og estetikk har jeg funnet to masterstudier på det kunstfagdidaktiske feltet som bruker en kreativt refleksiv analysemetode i møte mellom styringsdokumenter og eksisterende teori (Flæsen, 2018; Granløv, 2014). Disse studiene har vært til inspirasjon i oppbygning av denne artikkelen. Montuori legitimerer en kreativ refleksiv inngang slik:

One can engage the literature as a «thing» out there that needs to be digested and regurgitated at the appropriate time or as a living dialogue in which one can bring all of one's lived experience, questions, and creativity. (Montuori, 2005, s. 379)

For meg som lærer-forsker åpner en kreativ refleksiv inngang til styringsdokumenter og teori opp ikke bare for praksiserfaringer, men også for undring, spørsmål, tegninger og refleksjoner i møte med det jeg leser, analyserer og tolker.

Det første skritt i en kreativ refleksiv inngang er å velge relevante styringsdokumenter som bidrar til å skape de mulighetsrom jeg er ute etter. Jeg leser styringsdokumentene med en induktiv forskningslogikk, så åpent som mulig, hvorpå jeg analyser dem med utgangspunkt i egne tolkninger som lærer-forsker. I denne prosessen forsøker jeg å være åpen for de mulighetene som utkrystalliserer seg mellom styringsdokumentene og meg som leser. Den kreativt refleksive analysen resulterer, gjennom valgte styringsdokumenter og mine fortolkninger, i at mulighetsrom mellom inkludering og estetisk tilnærming til læring kommer til syne. Disse har jeg så med meg når jeg siden skal se på eksisterende fag- og forskningsteori.

Neste skritt er å undersøke fag- og forskningsteori. Først gjelder det å gjøre et utvalg av teori, da jeg ikke kan analysere alt. Denne gang har jeg en mer styrt, eller mer deduktiv, tilnærming. Jeg er styrt av de mulighetsrom jeg skapte $i$ analysen av styringsdokumentene. Jeg leter nå aktivt etter eksisterende fag- og forskningsteori som kan bekrefte, eller avkrefte, mulighetsrommene jeg skapte i de ulike styringsdokumentene. Det er først ved hjelp av faglitteratur jeg kan skape et mulighetsrom midt imellom det intensjonale (styringsdokumenter) og fag- og forskningsteori (som reflekterer det virksomme) (Randers-Pehrson, 2016). Til slutt i artikkelen vil jeg, 


\section{A. M. Kristoffersen}

basert på to-trinns-analysen, foreta en drøfting av potensielle mulighetsrom som oppstår med utgangspunkt i det intensjonale og det virksomme i relasjon i lys av forskningsspørsmålet.

\section{Analyse - å skape begynnelser for nye mulighetsrom}

I valg av styringsdokument er det det som styrer skolen i dag, som har vært viktig for meg å undersøke. Styringsdokumentene som er valgt er overordnede nasjonale og internasjonale dokumenter innenfor inkludering og estetisk tilnærming til læring. Norge som nasjon har aktivt vedtatt de internasjonale dokumentene, og som medlem av Unesco har vi sluttet oss til dem. De internasjonale vedtakene er med å styre det intensjonelle og det virksomme rommet i skolen.

Salamanca-erklceringen (Unesco, 1994) er et viktig styringsdokument i denne sammenhengen. Det bidro til at inkludering ble skrevet inn som et styrende element i norsk skole gjennom L-97 få år etterpå (Strømstad, Nes \& Skogen, 2004). Det samme er den nye overordnede delen - Overordnet del - verdier og prinsipper for oppleringen (Utdanningsdirektoratet, 2017) av den fornyede, eksisterende læreplanen K-06 og Opplæringslovens $\ 9$ (Opplæringsloven, 1998, \9A), som ble endret i 2017. Den overordnede delen vil prege skolerommet i mange år framover siden den nettopp har trådt i kraft når denne artikkelen skrives. Paragraf 9 og paragraf 9A gir føringer for skolens arbeid med inkludering og aktive arbeid for å hindre mobbing og ekskludering. Meld. St. 28 (Kunnskapsdepartementet, 2016) og NOU 2015: 2 (NOU 2015: 2) er ikke nødvendigvis styrende i samme grad lenger, da både stortingsmeldinger, NOU-er, rapporter og utredninger blir gjenstand for drøfting og strategier for fremtiden fra det tidspunktet de ble publisert. Samtidig gjør det at de er viktige å ha med i denne artikkelen, da de kan vise muligheter som ikke alltid blir videreført. Også Road Map for Arts Education (Unesco, 2006), og Seoul Agenda: Goals for the Arts Education (Unesco, 2010) er sentrale internasjonale dokumenter som er mindre kjent i norsk grunnskolesammenheng. Dette ble bekreftet for meg etter min e-postkontakt i juni 2018 med Kunnskapsdepartementet. ${ }^{1}$ På spørsmål til departementet om hvordan de jobber med å oppfylle målene fra Road Map og Seoul Agenda fikk jeg svar som vist $\mathrm{i}$ bilde 1 .

Tre plasser i svaret beskrives det at «regjeringen er opptatt av å styrke de praktisk estetiske fagene», men e-posten beskriver svært lite om hvordan KD faktisk følger opp de signerte Unesco-avtalene. Det uavklarte forholdet fra KD sin side til disse to Unesco-dokumentene gjør det enda viktigere for meg å ha med de to styringsdokumentene i denne analysen.

De styringsdokumentene jeg dermed har med i analysen vises i tabell 1 .

\footnotetext{
${ }^{1}$ E-postkorrespondanse med Kunnskapsdepartementet den 21.06.2018.
} 
Bilde 1. Svar fra Kunnskapsdepartementet i juni 2018.

21. jun. 2018,09:44 ڤै

Hei

Beklager at dette har tatt litt tid. Under har jeg prøvd ả samle litt informasjon som besvarer ditt sparsmäl.

De praktiske og estetiske fagene i skolen (musikk, kunst og hảndverk, kroppsoving og mat og helse) er sentrale og viktige. Dette er viktige danningsfag som bidrar til à gi elevene den kompetansen de trenger for videre utdanning og deltakelse i samfunnet for øvrig. Regjeringen er opptatt av at de styrkes og har besluttet à legge fram en strategi for de praktiske og estetiske fagene.

Pả linje med de ovvige fagene i grunnskolen, skal de praktiske og estetiske fagene giennomgás og utvikles som en del av den pågáende fagfornyelsen. Utdanningsdirektoratet har ná oversendt forslag til kjerneelementer - det viktigste elevene skal lære i alle fag - til Kunnskapsdepartementet. Kjerneelementene skal fastsettes i løpet av juni og de legger grunnlaget for læreplanutviklingen som skal gjøres det kommende áret. Du kan lese mer om fagfornyelsen her. hittps://www.udir.nolfagoornyelsen.

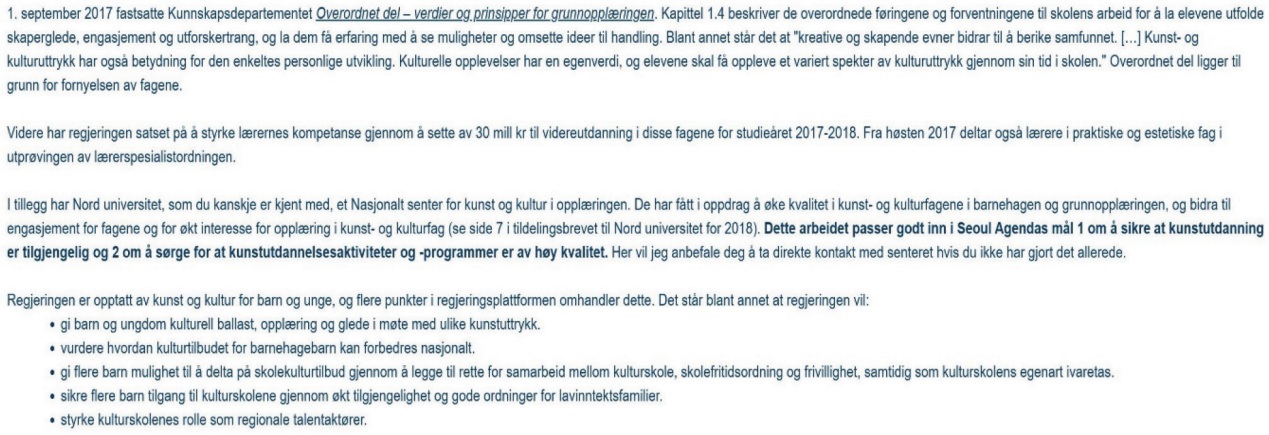

Tabell 1. Styringsdokumenter brukt i analysen for å skape krysningspunkt som kan bli mulighetsrom i relasjonen mellom inkludering og estetisk tilncerming til laring.

\begin{tabular}{|c|c|}
\hline Inkludering & Estetisk tilnærming til læring \\
\hline Salamanca-erklæringen (Unesco, 1994) & $\begin{array}{l}\text { Unesco - Road map } 06 \text { (Unesco, 2006) } \\
\text { Unesco - Seoul agenda } 10 \text { (Unesco, 2010) }\end{array}$ \\
\hline $\begin{array}{l}\text { Den nye overgripende delen i læreplanen } \\
\text { (Utdanningsdirektoratet, 2017) }\end{array}$ & $\begin{array}{l}\text { Den nye overgripende delen i læreplanen } \\
\text { (Utdanningsdirektoratet, 2017) }\end{array}$ \\
\hline 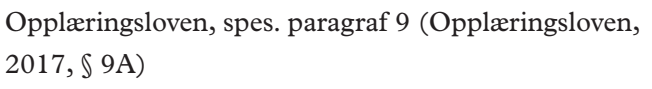 & Opplæringsloven (Opplæringsloven, 1998, \1-1) \\
\hline Meld. St. 28 (2015-2016) & Meld. St. 28 (2015-2016) \\
\hline Fag - Fordypning - Forståelse - En fornyelse av & Fag - Fordypning - Forståelse - En fornyelse av \\
\hline Kunnskapsløftet (Kunnskapsdepartementet, 2016) & Kunnskapsløftet (Kunnskapsdepartementet, 2016) \\
\hline $\begin{array}{l}\text { NOU 2015: } 2 \text { A høre til - Virkemidler for et trygt } \\
\text { psykososialt skolemiljø. (NOU 2015: 2) }\end{array}$ & $\begin{array}{l}\text { NOU 2015: } 2 \text { A høre til - Virkemidler for et trygt } \\
\text { psykososialt skolemiljø. (NOU 2015: 2) }\end{array}$ \\
\hline
\end{tabular}

Flere dokumenter er med på begge sider av tabell 1 fordi de begge potensielt kan si noe om både inkludering og om estetisk tilnærming til læring. I analysearbeidet ble definisjonen av inkludering under kolonnen av styringsdokumentene sentral. Ord 


\section{A. M. Kristoffersen}

eller avsnitt ble uthevet med utgangspunkt i hvordan jeg forsto definisjonen både praktisk som lærer og som forsker. I etterkant ble det samme gjort med estetisk tilnærming til læring. Dette var en nærlesingsprosess hvor definisjonen av begrepene, min erfaring som lærer, og en forståelse av begrepet transformasjon, ble styrende. Gradvis gikk min nærlesningsprosess over til å la blikket hvile på hvor krysningspunktet mellom inkludering og estetisk tilnærming til læring var. Sammenfallende krysningspunkt begynte da å oppstå som mulighetsrom jeg kunne se. Tabellen under viser de potensielle mulighetsrommene med sammenfallende krysningspunkt fra både inkludering og estetisk tilnærming til læring.

Tabell 2. Analysen av styringsdokumentene i forkortet form. Tabellen viser hvor de potensielle krysningspunktene mellom inkludering og estetisk tilncerming til laring skaper nye mulighetsrom. Se vedlegg 1 for analysen i sin helhet.

\begin{tabular}{|c|c|c|}
\hline Inkludering & Mulighetsrom & Estetisk tilnærming til læring \\
\hline $\begin{array}{l}\text { «... combating discriminatory attitudes, } \\
\text { vrating welcoming communities, building } \\
\text { an inclusive society ...» (Unesco, 1994, } \\
\text { s. ix) } \\
\text { «... løse konflikter på en fredelig måte ...» } \\
\text { (Utdanningsdirektoratet, } 2017, \text { s. 9) } \\
\text { «samhandling i et flerkulturelt samfunn» } \\
\text { (Kunnskapsdepartementet, 2016, s. 38) } \\
\text { "... et trygt psykososialt skolemiliø ...» } \\
\text { (NOU 2015: } 2 \text {, s. } 31 \text { ) }\end{array}$ & Fredskultur & $\begin{array}{l}\text { «... culture of peace.» (Unesco, 2006, } \\
\text { s. 5) } \\
\text { «... foster democracy and peace in } \\
\text { communites» (Unesco, 2010, s. 10) }\end{array}$ \\
\hline $\begin{array}{l}\text { "... creative involment of teachers and } \\
\text { staff ...» (Unesco, 1994, s. 24) } \\
\text { «Kreativitet er en viktig egenskap ...» } \\
\text { (Kunnskapsdepartementet, 2016, s. 24) } \\
\text { "... kreativitet ...» (NOU 2015: 2, s. 170) }\end{array}$ & Kreativitet & $\begin{array}{l}\text { "... creativity is the application of } \\
\text { imagination» (Unesco, 2006, s. 7) } \\
\text { "Creative learners needs creative teaching» } \\
\text { (Unesco, 2006, s. 8) } \\
\text { "to foster creative and innovative capacity» } \\
\text { (Unesco, 2010, s. 8) } \\
\text { "uttrykke seg på ulike måter, ... løse } \\
\text { problemer og stille nye spørsmål (Unesco, } \\
2010, \text { s. 8) }\end{array}$ \\
\hline $\begin{array}{l}\text { "... kulturell bevissthet» } \\
\text { (Utdanningsdirektoratet, } 2017, \text { s. 6) } \\
\text { "... mangfoldig fellesskap» } \\
\text { (Utdanningsdirektoratet, } 2017, \text { s. 6) } \\
\text { "respekt for forskjellighet.» } \\
\text { (Kunnskapsdepartementet, } 2016 \text { s. } 21 \text { ) } \\
\text { "accommodate all children» (Unesco, 1994, } \\
\text { s. 6) } \\
\text { "mangfoldig samfunn det respekt for } \\
\text { diversitet er viktig» (NOU 2015: } 2, \text { s. } 154 \text { ) }\end{array}$ & $\begin{array}{l}\text { Kulturell } \\
\text { bevissthet }\end{array}$ & $\begin{array}{l}\text { «cultural awerness» (Unesco, 2006, s. 6) } \\
\text { «cultural diversity» (Unesco, 2006, s. 6) } \\
\text { «understanding of diverse cultural and } \\
\text { artistic expressions» (Unesco, 2010, } \\
\text { s. 10) } \\
\text { «innsikt i kulturelt mangfald» } \\
\text { (Opplæringsloven } \ 1-1 \text { ) }\end{array}$ \\
\hline
\end{tabular}


Tabell 2. (forts.)

\begin{tabular}{|c|c|c|}
\hline Inkludering & Mulighetsrom & Estetisk tilnærming til læring \\
\hline $\begin{array}{l}\text { «sansing og tenkning, estetiske } \\
\text { uttrykksformer og praktiske aktiviteter» } \\
\text { (Utdanningsdirektoratet, 2017, s. 7) } \\
\text { «them to participate fully in development» } \\
\text { (Unesco, 1994, s. 22) } \\
\text { «få øve på, erfare og praktisere } \\
\text { demokratiske prosesser i praksis» } \\
\text { (Kunnskapsdepartementet, 2016, s. 38) } \\
\text { «adekvate uttrykk for følelser ... engasjement } \\
\text { i læringsaktivitetene.» (NOU 2015: 2, s. 122) }\end{array}$ & $\begin{array}{l}\text { Følelsesmessig } \\
\text { engasjement }\end{array}$ & $\begin{array}{l}\text { «emotional involment» (Unesco, 2006, s. 5) } \\
\text { «å utfalde skaparglede, engasjement og } \\
\text { utforskartrang» (Opplæringsloven } ₫ 1-1 \text { ) }\end{array}$ \\
\hline $\begin{array}{l}\text { «ulikheter anerkjennes og verdsettes» } \\
\text { (Utdanningsdirektoratet, 2017, s. 6) } \\
\text { «human dignity» (UNESCO, 1994, s. 11) } \\
\text { «likeverd» (Kunnskapsdepartementet, } \\
\text { 2016, s. 6) } \\
\text { «elevers likeverd» (NOU 2015:2, s. 154) }\end{array}$ & Likeverdighet & «dignity» (Unesco, 2006, s. 4) \\
\hline $\begin{array}{l}\text { «focused upon their impairments rather } \\
\text { than their potential» (Unesco, 1994, s. 7) } \\
\text { «elevenes dybdelæring og } \\
\text { grunnleggende kompetanse i fagene» } \\
\text { (Kunnskapsdepartementet, 2016, s. 7) } \\
\text { «sosiale og emosjonelle kompetanser er noe } \\
\text { som kan utvikles og læres gjennom hele } \\
\text { livet» (NOU 2015: 2, s. 126) }\end{array}$ & Utvikling & $\begin{array}{l}\text { "full development of the human personality } \\
\text { and to the strengthening of respect for } \\
\text { human rights and fundamental freedoms» } \\
\text { (Unesco, 2006, s. 4) } \\
\text { "development (creative, cognitive, } \\
\text { emotional, aesthetic and social)» (Unesco, } \\
\text { 2010, s. 3) } \\
\text { "utfordringar som fremjar danning og } \\
\text { lærelyst» (Opplæringsloven } \ 1-1 \text { ) } \\
\text { "skapende læringsprosesser også } \\
\text { en forutsetning for elevenes } \\
\text { danning og identitetsutvikling» } \\
\text { (Utdanningsdirektoratet, 2017, s. 8) }\end{array}$ \\
\hline
\end{tabular}

Med utgangspunkt i analysen av styringsdokumentene skapte jeg altså seks mulighetsrom mellom inkludering og estetisk tilnærming til læring. Disse er: fredskultur, kreativitet, kulturell bevissthet, følelsesmessig engasjement, likeverdighet og utvikling. Disse mulighetsrommene utgjør utgangspunkter i mitt videre arbeid der jeg ved hjelp av fag- og forskningsteori folder ut mulighetsrommene for læreren. Mulighetsrommene er skapt gjennom krysningspunkt mellom inkludering og estetisk tilnærming til læring.

\section{Mulighetsrom mellom inkludering og estetisk tilnarming til laring}

I dette underkapittelet fortsetter jeg å bygge ut mulighetsrommene gjennom å skape en diskusjon opp mot fag- og forskningsteori. Siden omfanget av litteratur er stort, har jeg aktivt måttet ta valg, og bortvalg. Den litteratur jeg velger, kommer fra ulike 


\section{A. M. Kristoffersen}

kunnskapssyn og fra ulike tider, på måter som ikke alltid passer helt sammen. Jeg forholder meg likevel performativt til den fag- og forskningslitteratur jeg velger og forsøker aktivt å skape mulighetsrommene gjennom en performativ bevissthet(Gergen \& Gergen, 2018, s. 63), der mitt perfomative blikk blir ledet av min posisjon som lærer-forsker. I diskusjonen vil sentrale områder som bygger ut mulighetsrommene markeres med understrekning.

\section{Fredskultur}

Når jeg forsøker å åpne opp et mulighetsrom giennom begrepet fredskultur i møte mellom teori om inkludering og estetisk tilnærming til læring har jeg valgt følgende teori: Ingrid Lund, Anne Helgeland og Velibo Bobo Kovac (Lund, Helgeland \& Kovac, 2017) og John Dewey (Dewey, 1934/1980; Dewey, 2008). Valget henger sammen med at Dewey har en grunnleggende sosial forståelse av læring (Dewey, 2008, s. 25). Lund, Helgeland og Kovac på sin side har en relasjonell og sosial teori om ekskludering i skolen, en mobbeteori. Deres teori påviser verdien av å se på kulturen rundt ekskluderende elementer i skolen.

For å knytte mulighetsrommet fredskultur opp mot skolen velger jeg dermed en mobbeteori som har et kollektivt fokus på strukturene rundt mobbing. «Mobbing av barn er handlinger fra voksne og/eller barn som hindrer opplevelsen av å høre til, å være en betydningsfull person i fellesskapet og muligheten til medvirkning» (Lund, Helgeland \& Kovac, 2017, s. 6). Ut fra forståelsen av mulighetsrommet fredskultur blir denne definisjonen interessant, fordi man da har fokus på kulturen hvor ekskludering skjer. En mobber kan fort bli en kategori som lar kulturen gå fri fordi man har funnet en syndebukk. Med et større sosialt fokus skjer ikke nødvendigvis det. Fra mulighetsrommet fredskultur må jeg som voksen like gjerne stille meg spørsmålet: «Kan mine handlinger utgjøre et hinder for at andre hører til, blir hindret i muligheter for medvirkning eller fra å kjenne seg som en betydningsfull person i fellesskapet?». Selv om det ikke nødvendigvis er bevisste handlinger, så kan egen handlemåte ubevisst være med på å skape et hinder for mulighetsrommet fredskultur. Dette kan endres når fokuset ligger på de sosiale strukturene og kulturen jeg er en del av, fordi jeg er også en viktig del av kulturen jeg opererer i og blikket mitt er farget av det. Hvis hindringer av fredskultur skal spores, så må kritiske spørsmål like mye stilles til meg selv, som til andre og den kulturen jeg er omgitt av.

Gjennom opplevelsesdimensjonene skolekulturen tilbyr kan inkludering og estetisk tilnærming til læring møtes $\mathrm{i}$ et krysningspunkt i mulighetsrommet fredskultur. Hvis man legger Deweys (1934/1980) estetiske teori til grunn, tilbys medvirkning og muligheten til å være betydningsfull gjennom formskapende aktiviteter, da det i det formskapende arbeide ikke skilles mellom form og innhold. Dewey uttrykker at alt formskapende arbeid er språk, språk i vid forstand. Formen uttrykker noe som ikke kan skilles fra innholdet. Hos Dewey forståes dette som form og substans: «All language, whatever its medium, involves what is said and how it is said, or substance and form» (Dewey, 1934/1980, s. 111). Det er også slik at formen kan hindre 
medvirkning, selv om innholdet i undervisningen tilbyr medvirkning. Sitter elevene f.eks. på rekke og rad i klasserommet, så er det mange former for aktiv medvirkning som undervisningsformen ikke tilbyr. Om fokuset på undervisngen ligger mer på innholdet i et "hva", og ikke også på et "hvordan", så vil noe av opplevelsesdimensjonen i fellesskapet falle bort. I mulighetsrommet fredskultur tilbys det opplevelse gjennom formgivende aktivitet. I en pedagogisk og didaktisk kontekst, kan det stilles spørsmål til hvordan man kan tenke tanken annerledes i neste aktivitet, og om noen hindres fra å være medvirkende i en bestemt aktivitet. Slik kan mulighetsrommet fredskultur i krysningspunktet mellom inkludering og estetisk tilnærming til læring tilby noe annet enn en statisk posisjon utenfor fellesskapet.

Mulighetsrommet fredskultur kan skapes om det støttes opp av de sentrale områdene som kommer til syne/skrives frem: de sosiale strukturene, form og innhold og opplevelse gjennom formgivende aktivitet.

\section{Kreativitet}

Når jeg forsøker å åpne opp mulighetsrommet kreativitet i møte mellom teori om inkludering og estetisk tilnærming til læring, har jeg valgt teorier fra Gert Biesta (2009), John Dewey (1934/1980), Hansjörg Hohr (2009) og Ken Robinson (2017). De har alle et fokus på skapende og kreativ virksomhet i skolen. Siden jeg har et sosialt ståsted i denne artikkelen, fokuserer jeg på fag og forskningslitteratur som åpner opp for hvordan kreativitet utvikles i skolekulturen som en del av den sosiale settingen, og ikke et individuelt perspektiv som fremhever talentutvikling hos den enkelte. Hohr (2009) blir i tillegg valgt fordi han kommer med en rekonstruksjon av Deweys teorier.

Den kritiske pedagogen Biesta definerer kreativitet som «en handling der man bringer noe nytt til verden, noe som ikke fantes der før» (Biesta, 2009, s. 133). Fokuset som Biesta har her ved å legge vekt på skapende handlinger, tolker jeg som et perfomativt syn på pedagogikk. Hos Dewey kan man forstå at det som setter det skapende i gang mot en erfaring, er motstand. Når individet møter motstand, er det alltid i relasjon til noe i den ytre verden, til omgivelsene. Motstanden sparker erfaringen i gang (Dewey, her i Hohr, 2009, s. 66). Og det er ikke bare ved motstand i seg selv at det skapende eller kreative skjer. Det kreative kan oppstå når motstand ikke betraktes som et hinder som skal overvinnes, men mer som en invitasion (Dewey, 1934/1980, s. 45). Det er når motstanden omskapes, at noe nytt kan skapes ut av noe gammelt. Dewey bruker begrepet transformasjon (s. 76) til å beskrive denne motstandsprosessen.

Når mulighetsrommet kreativitet kobles til inkludering, er det gjennom måten man møter omgivelsene på. Å tenke tanken annerledes for å prøve å skape et opplevd fellesskap, er å la mostand være en invitasjon til ettertanke der man forestiller seg noe nytt. Innenfor estetisk tilnærming til læring så finnes det elementer av det samme. Å være skapende i formgivende aktiviteter er å utsette seg for motstand i form av kreative impulser. Ken Robinson har skrevet en rekke bøker om kreativitet i skolen. Han påpeker at «Creativity involves putting your imagination to work. In a sense, creativity 


\section{A. M. Kristoffersen}

is applied imagination» (Robinson, 2017, s. 121). I en pedagogisk og didaktisk kontekst, er det avgjørende hvordan man skaper rom der kreativitet kan føre til skapende handlinger.

Mulighetsrommet kreativitet i krysningspunktet mellom inkludering og estetisk tilnærming til læring kan tilby muligheter for transformasjoner der noe nytt skapes. Områdene som støtter opp under mulighetsrommet kreativitet, er: en invitasjon, transformasjon og tenke tanken annerledes.

\section{Kulturell bevissthet}

Når jeg forsøker å åpne opp mulighetsrommet kulturell bevissthet i møte mellom teori om inkludering og estetisk tilnærming til læring, har jeg valgt teori fra Jonathan D. Jansen (2009). Jansens post-konflikt-pedagogikk (2009) bygger på erfaringer med å jobbe mot undertrykking og undertrykkende strukturer gjennom å åpne opp for et dialogisk rom i en sørafrikansk kontekst. Hans pedagogiske syn legger vekt på hvordan en kan manøvrere, tenke og handle i et klasserom der det er et stort mangfold og rasekonflikter, slik som i Sør-Afrika. Jeg skal under redegjøre kort for hans teori, og begrunne hvorfor den åpner opp mulighetsrommet kulturell bevissthet der inkludering og estetisk tilnærming til læring krysses.

Bak Jansens post-konflikt-pedagogikk ligger det i bunnen en forståelse av et dialogisk mangfoldsperspektiv, som omhandler hvordan man kan arbeide aktivt mot alt det som segregerer: "...the presence and the passion of the "other» enables the clash with and engagement of conflicting and conflicted knowledges» (Jansen, 2009, s. 152). Jansen argumenterer for at det er tre nøkkelelementer i en slik pedagogikk: "...the disruption of received knowledge; the significance of pedagogic dissonance; and the importance of hope» (Jansen, 2009, s. 153). Det første nøkkelelementet, the disruption of received knowledge, kan på norsk forstås som forstyrrelser i allerede tilegnet/nedarvet kunnskap. I dette nøkkelelementet relateres ny kunnskap til den kunnskap en har tilegnet seg fra det kulturelle perspektivet man har vokst opp med. Det kan forstås som summen av ens kulturarv. Begrepet disruption kan oversettes til å forstyrre. Det handler om å se og anerkjenne hvor de ulike kulturelle perspektivene og ytringene kommer fra, samtidig som disse utfordres (Jansen, 2009, s. 153). Rent konkret kan det forstås slik at man som pedagog ikke forholder seg til offisielle sannheter knyttet til historien, men relaterer til studentenes/elevenes sannheter. Man prøver å lytte inn narrativenes kulturelle utgangspunkt, og utfordrer disse. Det andre nøkkelelementet er significance of pedagogical dissononace (Jansen, 2009, s. 154). Det er et nøkkelelement som omhandler undertrykkende strukturer, og hvor det pedagogiske ansvaret ligger $\mathrm{i}$ å åpne opp for dissonansen, for andre underliggende stemmer, innenfor den hverdagslige undervisningssettingen. Gjennom å invitere noe fram, og relatere til det, kan det langsomt åpnes opp for bredere forståelser som kan arbeide mot undertrykkende strukturer. Det tredje nøkkelelementet som Jansens initierer, er importance of hope. Håp skapes gjennom at man åpner opp for ulike narrativer/ fortellinger, men også gjennom annerkjennelse av de ulike nedarvete erfaringer hver 
enkelt kan ha. "This kind of critical pedagogy recognizes the power and the pain at play in school and society, and their effects on young people, and then asks "how" things could be better» (Jansen, 2009, s. 154-155). Gjennom å dele fortellinger, og samtidig anerkjenne det som er erfart, skapes håp om noe nytt for de som opplever denne sosiale settingen.

Ved hjelp av Jansens post-konflikt-pedagogikk åpner jeg opp mulighetsrommet $k u l-$ turell bevissthet. Teorien er interessant fordi den skaper grobunn for at ulike erfaringer og fortellinger for mennesker med ulike bakgrunner kan komme til uttrykk, og samtidig forstyrrer den allerede etablerte sannheter. Både inkluderingsteori og estetisk teori krysses i mulighetsrommet kulturell bevissthet. Ut fra en inkluderingsforsåelse etterstreber teorien å åpne opp for mangfold i praksis. Den ivaretar også en estetisk forståelse gjennom å være en handlingsteori som omhandler det å lytte inn og sanse det som skjer ut fra et nærværsperspektiv.

Mulighetsrommet kulturell bevissthet kan skapes i krysningspunktet mellom inkludering og estetisk tilnærming til læring gjennom at offisielle sannheter blir utfordret, og nye virkeligheter blir skapt gjennom konfrontasjon, deltagelse og nærvær. Områdene som støtter opp under mulighetsrommet kulturell bevissthet er: lytte inn, åpne opp for dissonans og håp.

\section{Følelsesmessig engasjement}

Når jeg forsøker å åpne opp mulighetsrommet følelsesmessig engasjement i møte mellom teori om inkludering og estetisk tilnærming til læring, har jeg valgt teori fra Dewey (1934/1980), Hohr (2009) og Arne Næss (2008). Dewey og Hohr skriver begge om kunstens betydning i en læringskontekst, og dermed åpner de opp for det følelsesmessige i pedagogikken. Filosofen Næss omtaler både viktigheten av mangfold og følelsenes betydning giennom en filosofisk retning kalt dypøkologi.

Dewey, som her tolkes ut fra et estetisk perspektiv, understreker, at "...nothing takes root in mind when there is no balance between doing and receiving» (1934/1980, s. 45). De mest grunnleggende aspektene for å skape denne balansen i erfaringen og dermed også i sinnet, er "aksjon, emosjon og kognisjon" (Hohr, 2009, s. 67). Ut fra Dewey kan det hevdes at det er det følelsesmessige og emosjonen som binder aksjonen sammen med kognisjonen. Det følelsesmessige blir selve grunnlaget for en læring som ikke bare sitter i hodet, men i hele kroppen: "'Impulsion” designates a movement outward and forward to the whole organism to which special impulses are auxiliary» (Dewey, 1934/1980, s. 58). Impulsion kan forståes som en vital impuls som er en livskraftig innskytelse til handling. Denne handlingen skaper bevegelse mot noe som ikke er forutbestemt, og $\underline{i k k e}$ målbasert. Impulsion er menneskets kraft som oppstår i møte med omgivelsene, den er en livskraftig handling. Hos Dewey forstår jeg at en slik livskraftig handlig er estetisk, da det er en kraft som skapes med utgangspunkt i det sanselige og det følelsesmessige engasjementet hos mennesket (Dewey, 1934/1980, s. 43). Med utgangspunkt i Dewey (1934/1980) og Hohr (2009) har estetisk tilnærming til læring et omdreiningspunkt rundt følelsesmessig engasjement. 


\section{A. M. Kristoffersen}

En lignende kobling, der det følelsesmessige engasjementet blir vektlagt, kan jeg finne innenfor teori som omfatter inkludering, i denne sammenhengen dypøkologi.

Dypøkologi som filosofisk retning beskrives betydningen av inkludering og mangfold, som ikke-voldelighet i forskning og i kommunikasjon: «Deep ecology supporters appreciate the inherent value of all beings and of diversity. Therefore, research and communication should be inclusive and nonviolent» (Naess, 2008, s. 3). I dypøkologien er det følelsesmessige i møte med naturen et viktig omdreiningspunkt:

From the mountains, we learn modesty; their size makes us feel small and humble, so we participate in their greatness. Be nonviolent in language, judgment, and action. Emphasize positive, active feelings. The more diversity the better. All things are open to inquiry. (Naess, 2008, s. 17-18)

Dypøkologien åpner for et følelsesmessig engasjement som kan kobles til mangfold og inkludering. I mulighetsrommet følelsesmessig engasjement møtes inkludering og estetisk tilnærming til læring gjennom måten de begge tilbyr opplevelse som oppstår gjennom aktivitet og søken. Et engasjement som også griper lærere og elever emosjonelt, og som kan føre til nye handlinger. Det følelsesmessige blir bindeleddet mellom det man gjør i aktiviteten og det man tenker/erkjenner.

I et pedagogisk og didaktisk perspektiv tilbyr mulighetsrommet følelsesmessig engasjement i krysningspunktet mellom inkludering og estetisk tilnærming til læring et opplevelsesbasert læringsperspektiv. Områdene som støtter opp under mulighetsrommet følelsesmessig engasjement, er: aksjon, emosjon og kognisjon, det ikke-målbaserte og ikke-voldelighet.

\section{Utvikling}

Når jeg forsøker å åpne opp mulighetsrommet utvikling i møtet mellom teori om inkludering og estetisk tilnærming til læring, har jeg valgt Peder Haugs teori omkring inkludering (Haug, 2004a, 2004b), og performativ læringsteori beskrevet av Thomas Dahl og Tone Pernille Østern (2019).

Det er ulike måter å se utvikling på. En måte som blir brukt i norsk skole er Pisa-undersøkelsene. Men i mulighetsrommet utvikling velger jeg en annen måte enn det målte og de sammenlignende perspektivene Pisa-undersøkelsene åpner for. Dette fordi perspektivtaking og det å bruke sine skapende evner også er nødvendige kvaliteter om pedagogikken og didaktikken sammen skal skape størst mulig aktiv og intelligent deltagelse i retningen mot et bedre samfunn (Dewey, 2008, s. 29). På 2000-tallet kom Haug med en teori om virkeområder som må samvirke innenfor en inkluderende skole. Virkeområdene i hans teori er: demokratisering, deltagelse, utbytte og fellesskap (Haug, 2004a). Teorien om inkludering er konstruert rundt hvordan skolen kan være utviklende for alle. Deltagelse og utbytte relaterer han til utvikling for den enkelte: «Alle elever skal ha en opplæring som er til gavn for dem sosialt og faglig (Haug, 2004b, s. 170). Når det gjelder deltagelse, påpeker Haug: «Ekte deltaking er noe annet enn å være tilskuer». Aktiv deltagelse berører selvet, og skaper et utbytte 
som er til gavn både faglig og sosialt. Dette er det jeg tolker i Haugs omtalelse av ekte deltagelse, og dette vil skape utvikling.

I en antologi om læring gjennom en flerfaglig, relasjonell og skapende tilnærming har Dahl \& Østern (2019) skrevet om performativ læring. Dette skaper et interessant krysningspunkt med estetisk teori, når den sansende estetiske tilnærming kobles til definisjonen av performativ læringsteori. Den performative læringen forstås som «... kroppslig, relasjonell, skapende, affektiv og kognitiv læring - på en og samme gang. Vi kan kalle det for performativ læring, der læring forståes som skapende prosess» (Dahl \& Østern, 2019, s. 53). Et slikt syn på læring viser til en rekke perspektiver som arbeider sammen. Perspektivene har det til felles at læring skjer i og gjennom en skapende prosess, hvor de ulike delene ikke kan skapes eller forstås uavhengig av hverandre.

De ovenfornevnte teoriene om inkludering og estetisk tilnærming til læring knytter mulighetsrommet sammen giennom et utviklingsfokus som er både faglig og sosialt gjennom deltagelse. Skal deltagelse skapes, må læring og læringsarenaen by på læring som både er kroppslig, relasjonell, skapende, affektiv og kognitiv. Dette er en læring som tilbyr et både-og-perspektiv. Det viktigste for å legge til rette for utvikling både pedagogisk og didaktisk blir ikke da å se på begrensningene individer eller grupper har, men hvilke muligheter som finnes i det som kan skapes sammen.

Mulighetsrommet utvikling møtes i krysningspunktet mellom inkludering og estetisk tilnærming til læring gjennom at læring forstås som en skapende prosess. Områdene som støtter opp under mulighetsrommet utvikling er: ekte deltagelse, performativ læring og skapende prosess.

\section{Likeverdighet}

Når jeg forsøker å åpne opp mulighetsrommet likeverdighet i møte mellom teori om inkludering og estetisk tilnærming til læring, har jeg valgt teori fra Martin Buber (1992), Jacob Levy Moreno (Moreno, 2014; Rasmussen \& Kristoffersen, 2011), Fabio Dovigo (2017), og Aud Sæbø, Stig Eriksson \& Tor-Helge Allern (2017). Noe av omdreiningspunktet for dette mulighetsrommet blir møte-begrepet. Her forstås det ikke bare som et begrep knyttet til en filosofi, men også en praksis. Etterpå skapes krysningspunktet til inkludering og estetisk tilnærming til læring.

Det jeg forstår med mulighetsrommet likeverdighet er å møte den andre ansikt til ansikt. Møtebegrepet inneholder likeverdighet gjennom at det både handler om å bevare den andres annerledeshet og om en gjensidig annerkjennelse. Buber er en av de mest siterte filosofene innen humanistisk psykologi, mens mye tyder på at Moreno var en sentral inspirasjonskilde for Bubers møtebegrep (Moreno, 2014, s. 66; Rasmussen og Kristoffersen, 2011, s. 127). Buber vektlegger subjekt-subjektforholdet i møtet. Et subjekt-subjekt-forhold er basert på et likeverdighetsprisipp: «Jeg blir til ved Du-et. Idet jeg blir Jeg, sier jeg Du. Alt virkelig liv er møte» (Buber, 1992, s. 13). I en teaterfaglig kontekst kan et slikt møte også forstås som et rollebytte (Rasmussen \& Kristoffersen, 2011 s. 26). Gjennom et møte, ansikt til ansikt, øye til øye, skjer det noe signifikant med både meg og deg. Hos Moreno kan den 


\section{A. M. Kristoffersen}

samme type lekeverdighet gjenfinnes i teaterpraksis; at det jevnbyrdige møtet må gjenskapes igjen og igjen som en aldri avsluttet øvelse (Rasmussen \& Kristoffersen, 2011, s. 85). I denne artikkelen utgjør disse perspektivene, særlig med vekt på mulighetsrommet likeverdighet.

I denne analysen møtes inkludering og estetisk tilnærming til læring, og åpner opp for mulighetsrommet likeverdighet. I $2017 \mathrm{kom}$ to antologier omhandlende drama, teater og demokrati (Heggstad, Rasmussen \& Gjærum, 2017; Sæbø, Eriksson \& Allern, 2017). En målsetting var å samle norske forskere innenfor drama og teater og bidra med ny viten innen undervisning, utdanning, kultur og samfunn. Noen av perspektivene som kommer fram i antologiene kan være relevante med tanke på å åpne opp mulighetsrommet likeverdighet:

Drama- og teaterformer medfører muligheter til å uttrykke seg, involvere seg i meningsutveksling og meningsskaping, innta motstandspunkt og perspektivskifte, delta i dialogiske møter og få erfaring med å være i en helhetlig kommunikasjonssituasjon - sammen med andre og i prosess. (Sæbø, Eriksson \& Allern, 2017, s. 17)

En underliggende hypotese $\mathrm{i}$ antologiene «er at dramafagets estetiske læringsprosesser har et uutnyttet potensiale både med tanke på å utvikle gode demokratiske læringsfellesskap, demokratisk kompetanse og bedre og mer deltagende læreprosesser» (Sæbø, Eriksson \& Allern 2017, s. 14). Det å åpne opp for at dialogiske møter kan skapes, er å tilby muligheter for situasjoner hvor likeverdighet kan oppstå. Aktive innganger til læring som legger til rette for slike dialogiske møter, skaper helhetlige kommunikasjonssituasjoner.

Gjennom en vektlegging av møtebegrepet i mulighetsrommet likeverdighet åpnes det opp for en dialogisk og helhetlig kommunikasjon, da særlig med tilknytning til en praksis som handler om å ta den andres perspektiv gjennom rollebytte. Innenfor teori om inkludering finner man også perspektiver som understøtter et slik mulighetsrom. Ved å jobbe med å fjerne barrierer som skaper ekskludering, muliggjør man for graden av likeverdighet. En av disse barrierene er ifølge Dovigo arbeidsmåtene i skolen, og hvordan lærerplanenes målsetninger skal møtes.

One of the central tenets of inclusive education is that rather than forcing students to fit into existing educational programs, the curriculum has to be adapted to become accessible to all students. As long as only children are required to be flexible in order to adjust to a rigid curriculum or assessment, expanding teaching methods is not enough to avoid the push out effect and achieve inclusion. (Dovigo, 2017, s. 42)

Ifølge Dovigo, er det ikke tilstrekkelig bare å tenke aktive arbeidsformer, men også hvordan man som lærer kan tenke helt annerledes om lærerplaner og det som skal læres. Et kritisk punkt i dette perspektivet er at det må tenkes ut over at elever skal tilpasse seg læreplanene, da likeverdighet trolig ikke oppstår ved det. Kan tanken tenkes annerledes? Hva skjer om man tilpasser læreplanene til elevene? I mulighetsrommet likeverdighet i krysningspunktet mellom inkludering og estetisk tilnærming til læring, kan det være en interessant tanke. 
Pedagogisk og didaktisk støtter områdene møte, helhetlige kommunikasjonssituasjoner og tilpasse læreplanene til elevene opp under mulighetsrommet likeverdighet når de samvirker.

\section{I møte mellom inkludering og estetisk tilnærming til læring}

Utgangspunktet for denne artikkelen var følgende forskningsspørsmål: Hvilke pedagogiske og didaktiske mulighetsrom kan skapes $i$ mote mellom inkludering og estetisk tilncerming til lering gjennom à studere utvalgte styringsdokumenter som har relevans for skolen og eksisterende fag-og forskningsteori?

I møtet mellom styringsdokumenter og eksisterende teori innenfor inkludering og estetisk tilnærming til læring, har jeg gjennom denne litteraturstudien forsøkt å tegne konturene av nye mulighetsrom for pedagogisk og didaktisk arbeid i grunnskolen. I analysen av relevante styringsdokumenter for skolen, ble konturene av seks mulighetsrom i krysningspunkter mellom inkludering og estetisk tilnærming til læring utformet. Disse var: fredskultur, kreativitet, kulturell bevissthet, følelsesmessig engasjement, utvikling og likeverdighet. Videre utfoldet jeg mulighetsrommene ytterligere ved hjelp av et utvalg av fag- og forskningslitteratur fra feltene inkludering og estetisk tilnærming til læring. Undersøkelsen av fag- og forskningslittetaruren bidro til å forme de ulike mulighetsrommene ytterligere, gjennom relevante og meningsbærende begreper. Begrepene har jeg markert med understrekning underveis i litteraturgjennomgangen. I figur 1 skaper jeg et visuelt bilde av de ulike mulighetsrommene med de sentrale områdene som er et resultat av den kreative, refleksive analysen av styringsdokumenter, fag- og forskningslitteratur. Ved hjelp av figur 1 svarer jeg på forskningsspørsmålet som jeg har jobbet performativt-skapende med.

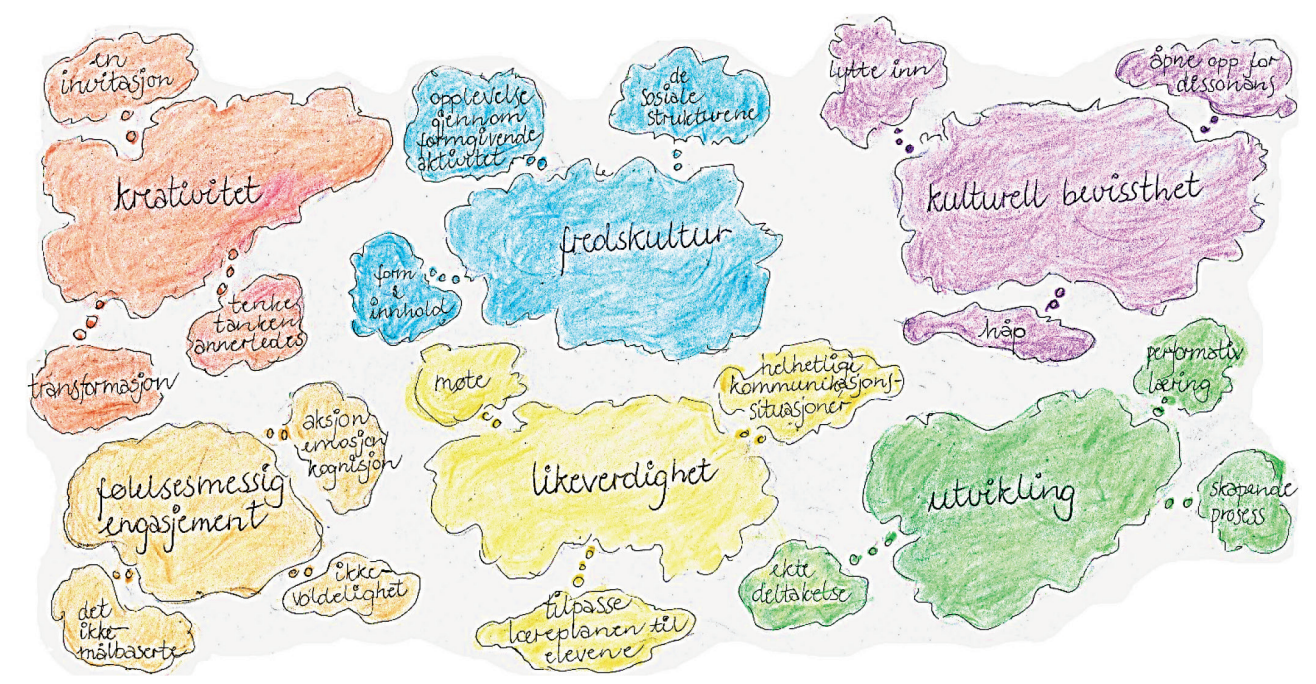

Figur 1. Mulighetsrom mellom inkludering og estetisk tilnærming til læring, bygget ut med begreper fra eksisterende forskning og fagteori. (Design: Anne Grete Mollan, 2020) 


\section{A. M. Kristoffersen}

I prosessen med denne artikkelen har mulighetsrommene blitt utviklet som tankebobler som blir støttet opp av ulike områder. Skolerommet blir gjennom disse mulighetsrommene åpnet opp. Som svar på den transformative prosessen vil jeg avslutningsvis oppsummere og diskutere hvilken betydning møtet mellom inkludering og estetisk tilnærming til læring kan ha pedagogisk og didaktisk, gjennom å vende tilbake til den innledene fortellingen om gutten.

\section{Konklusjon og artikulasjon av kunnskapsbidraget}

Artikkelen startet med en kort fortelling om en elev som hadde opplevd stor grad av isolasjon i sin «skoleverden» gjennom sin tilhørighet til «grupperommet». Skolen hadde inntil da ikke maktet å skape et felles skolerom som også kunne innbefatte ham. I fravær av erfaringer av et trygt skolerom hadde eleven søkt seg til et isolert grupperom. Hvis samme elev bringes med inn i denne studiens kontekst, så kan mulighetsrommene ha betydning både for det pedagogiske og didaktiske arbeidet. Mulighetsrommet fredskultur åpner for de sosiale strukturene rundt eleven, i stedet for å individforklare hans isolerte posisjon. Gjennom opplevelser i formgivende aktiviteter der form og innhold samvirker, vil han i større grad få mulighet til å være en del av et felles skolerom. I mulighetsrommet kreativitet blir utfordringen å skape et trygt felles skolerom for alle en invitasjon til å tenke tanken annerledes, som kan åpne for transformasjon der eleven gradvis kan omdefinere sin skoleverden. Kulturell bevissthet er et mulighetsrom som handler om å lytte inn elevens fortellinger, skape dissonans med hans og omgivelsenes offisielle sannheter, og igjen åpne opp for håp. Gjennom mulighetsrommet følelsesmessig engasjement sammenbindes aksjon, emosjon og kognisjon. Sagt på en annen måte innebærer det at handling, følelse og tanke ikke er adskilt, men knyttes sammen. Dette åpner for en læringsprosess som er bygget på ikke-voldelighet og det ikke-målbaserte. Utvikling er et mulighetsrom der eleven blir invitert til å være en ekte deltager i en skapende prosess, en performativ læringsprosess. I mulighetsrommet likeverdighet møter eleven et skolerom der alle elever er inkludert. Når alle er til stede i skolerommet, oppstår helhetlige kommunikasjonssituasjoner gjennom møter. Å ha fokus på å legge til rette for slike situasjoner i skolerommet er like gjerne å tilpasse læreplanen til elevene, i stedet for omvendt.

Pedagogisk og didaktisk tilbyr mulighetsrommene bygget på inkludering og estetisk tilnærming til læring at et utvidet skolerom gradvis kan skapes, også for eleven som søkte seg til grupperommet. Det pedagogiske og didaktiske nivået griper inn i hverandre både i analysen og i lærerens faktiske arbeid. Som innledningsvis definert, forstår jeg pedagogikk som undervisningens overordnede mål om å sikre størst mulig aktiv og intelligent deltagelse i retningen mot et bedre samfunn (Dewey, 2008, s. 29). Mulighetsrommene jeg har tegnet konturene av i denne artikkelen kan bidra til dette, og mulighetsrommene kan altså være aktive og performative på pedagogisk nivå. Didaktikk forstår jeg videre som utøvelse av undervisningskunsten (Bø \& Helle, 2007, s. 44), men på en måte som reflekterer det pedagogiske nivået. Det didaktiske 
nivået er altså et mer praksisnært nivå av lærerens arbeid, men de pedagogiske verdiene og prinsippene nedfeller seg i utøvelsen av undervisningskunsten. Også på didaktisk nivå kan mulighetsrommene være performative for lærerens arbeid. Slik fletter det pedagogiske og didaktiske seg sammen, både i denne analysen, og i lærerens arbeid i skolen.

Mulighetsrommene jeg har skapt i denne artikkelen er teoretiske, basert i eksisterende styringsdokumenter og et utvalg av fag- og forskningslitteratur. Det er lærerens og skoleorganisasjonens oppgave å utvikle mulighetsrommene for inkludering og estetisk tilnærming til læring $\mathrm{i}$ praksis, noe jeg håper at resultatene av denne artikkelen kan være et kunnskapsbidrag til og verktøy for. Mulighetsrommene gir videre gjennom lærernes faktiske, praktiske arbeid mulighet for at utdanningspolitikken i Norge oppfyller sine mål om inkludering som generelt læringsprinsipp nedfelt i overordnet del av læreplanen (Utdanningsdirektoratet, 2017, s. 4) og om å styrke estetiske tilnærminger til læring slik det er nedfelt i blant annet Unescodokumentene Road Map for Arts Education (Unesco, 2006), og Seoul Agenda: Goals for the Arts Education (Unesco, 2010).

\section{Forfatteromtale}

Audun Mollan Kristoffersen er ph.d.-stipendiat ved Huseby barneskole og NTNU, samtidig som han er lærer i Trondheim kommune. Formålet med hans prosjekt er å undersøke hvordan man kan bidra til gode læringsmiljøer for barn og unge gjennom utvikling av estetiske tilnærminger til læring, der inkludering står sentralt. Prosjektet er tenkt som et pedagogisk og didaktisk designsprosjekt på Huseby barneskole. Audun er utdannet spesialpedagog, har fordypning i drama, og er i tillegg utdannet playbackleder ved Centre for Playback Theatre.

\section{Referanser}

Buber, M. (1992). Feg og du. København: Hans Reitzels Forlag.

Biesta, G. (2009). Lering retur: Demokratisk dannelse for en menneskelig fremtid. København: Unge pedagoger.

Bø, I. \& Helle, L. (2007). Pedagogisk ordbok. Praktisk oppslagsverk i pedagogikk, psykologi og sosiologi. Oslo: Universitetsforlaget.

Dahl, T. \& Østern, T. P. (2019). Dybde//læring med overflate og dybde. I T. P. Østern, T. Dahl, A. Strømme, A. P. Petersen, A.-L. Østern \& S. Selander (Red.), Dybde//laring - en flerfaglig, relasjonell og skapende tilncerming (s. 39-56). Oslo: Universitetsforlaget.

Dewey, J. (1934/1980). Art as Experience. New York: Penguin Books.

Dewey, J. (2008). Erfaring og opdragelse. København: Hans Reitzels Forlag.

Dovigo, F. (2017). Linking theory to practice in inclusive education. I F. Dovigo (Red.), Special education needs and inclusive practice. An international perspective (s. 33-62). Rotterdam/Boston/Taipei: Sense Publishers.

Flæsen, T. O. (2018). Mulighetsrom mellom musikkfaget $i$ skolen og tilpasset opplcering - sett på tvers av styringsdokumenter og fagteori. (Masteroppgave). Trondheim: NTNU Norges teknisk-naturvitenskapelige universitet.

Gergen, K. J. \& Gergen M. (2018). I P. Leavy (Red.), Handbook of Arts-Based Research (s. 54-67). NY/London: The Guildford Press.

Granløv, U. (2014). Interkulturell pedagogikk $i$ estetisk perspektiv - en kreativt refleksiv litteraturstudie. (Masteroppgave). Trondheim: NTNU Norges teknisk-naturvitenskapelige universitet. 


\section{A. M. Kristoffersen}

Haug, P. (2004a). Hva forteller forskningen om integrering og inkludering i skolen. I J. Tøssebro (Red.), Integrering och inkludering (s. 169-198). Lund: Studentlitteratur.

Haug, P. (2004b). Fins den spesialpedagogiske kompetansen det er bruk for i skulen? Spesialpedagogikk, 69(5), 4-11.

Heggestad, K. M., Rasmussen, B. \& Gjærum, R. G. (Red.). (2017). Drama, teater og demokrati. Antologi 2. I kultur og samfunn. Bergen: Fagbokforlaget.

Hohr, H. (2009). Å føle, å oppleve, å begripe. En rekonstruksjon av John Deweys erfaringsbegrep. I K. Steinsholt \& S. Dobson (Red.), Verden satt ut av spill. Postmoderne pedagogiske perspektiver (s. 65-77). Trondheim: Tapir Akademisk Forlag.

Hohr, H. (2013). Den estetiske erkjennelsen. I A.-L. Østern, G. Stavik-Karlsen \& E. Angelo (Red.), Kunstpedagogikk og kunnskapsutvikling (s. 219-233). Oslo: Universitetsforlaget.

Jansen, J. D. (2009). On the clash of martyrological memories. Perspectives in Education, 27(2), 147-157.

Kunnskapsdepartementet. (2016). Fag - Fordypning - Forståelse - En fornyelse av Kunnskapsløftet. (Meld. St. 28 2015-2016). Hentet fra https://www.regjeringen.no/no/dokumenter/meld.-st.-28-20152016/id2483955/

Lund, I., Helgeland, A. \& Kovac, V. (2017). På vei mot en ny forståelse av mobbing i et folkehelseperspektiv. Acta Didactica Norge, 11(3), 1-19. https://doi.org/10.5617/adno.4691

Moreno, J. D. (2014). Impromptu man. F. L. Moreno and the Origins of Psychodrama, Encounter Culture, and the Social Network. New York: Bellevue Literary Press.

Montuori, A. (2005). Literature Review As Creative Inquiry: Reframing Sholarship As a Creative Process. Journal of Transformative Education, 3(4), 374-393. Hentet fra https://www.scribd.com/document/275782154/ Literature-Review-As-Creative-Inquiry

Naess, A. (2008). Ecology of Wisdom. Great Britain: Penguin Classics.

Nes, K. (2018). Missing recognition? Inclusive education and language. Minority students in Norwegian schools. I L. A. Kulbrandstad, T. O. Engen \& S. Lied (Red.), Norwegian Perspectives on Education and Cultural Diversity (s. 83-102). Newcastle upon Tyne: Cambridge Scholars Publishing.

Nordahl, T. (2018). Inkluderende fellesskap for barn og unge. Bergen: Fagbokforlaget.

NOU 2015: 2. (2015). A høre til-Virkemidler for et trygt psykososialt skolemiljø. Hentet fra https://www.regjeringen. no/no/dokumenter/nou-2015-2/id2400765/

Opplæringsloven. (1998). \1-1. Formålet med opplaringa (LOV-1998-07-17-61). Hentet fra https://lovdata.no/ lov/1998-07-17-61/\$1-1

Opplæringsloven. (2017). Kapittel 9A. Elevane sitt skolemiljø (LOV-2017-09-06-711). Hentet fra https://lovdata. no/lov/1998-07-17-61/\$9a-1

Randers-Pehrson, A. (2016). Tinglaging og leringsrom $i$ en kunst- og håndverksdidaktisk kontekst. (Doktorgradsavhandling). Oslo: Det utdanningsvitenskapelige fakultet, Universitetet i Oslo.

Rasmussen, B. \& Kristoffersen, B. (2011). Handling og forestilling - forestilling om handling. Trondheim: Tapir akademiske forlag.

Robinson, K. (2017). Out of our minds. The Power of Being Creative (3. utg.). New Delhi: Capstone.

Strømstad, M., Nes, K. \& Skogen, K. (2004). Hva er inkludering? Evaluering av Reform 97. (Rapport nr. 1). Elverum: Høgskolen i Hedmark.

Sæbø, A. B, Eriksson, S. A. \& Allern, T. H. (Red.). (2017). Drama, teater og demokrati. Antologi 1. I barnehage, skole, museum og høyere utdanning. Bergen: Fagbokforlaget.

Unesco. (1994). The Salamance statement and framework for action on special needs education. Hentet fra http:// www.unesco.org/education/information/nfsunesco/pdf/SALAMA_E.PDF

Unesco. (2006). Road Map for Arts Education. Hentet fra http://www.unesco.org/new/fileadmin/MULTIMEDIA/ HQ/CLT/CLT/pdf/Arts_Edu_RoadMap_en.pdf

Unesco. (2010). Seoul Agenda: Goals for the Development of Arts Education. Hentet fra http://www.unesco.org/ new/fileadmin/MULTIMEDIA/HQ/CLT/CLT/pdf/Seoul_Agenda_EN.pdf

Utdanningsdirektoratet. (2017). Overordnet del av laereplanverket. Hentet fra https://www.udir.no/lk20/ overordnet-del/

Østern, A.-L. (2010). Estetisk tilnærming til læring. I S. Stenersen Hovdenak \& O. Erstad (Red.), Kunnskap $i$ skolen (s. 181-197). Trondheim: Tapir akademiske forlag.

Østern, T. P., Dahl, T., Strømme, A., Petersen, A. P., Østern, A.-L. \& Selander, S. (Red.). (2019). Dybde//lering - en flerfaglig, relasjonell og skapende tilncerming. Oslo: Universitetsforlaget. 


\section{Vedlegg 1}

Tabell 2. Begynnelser til mulighetsrom mellom inkludering og estetisk tilnærming til læring giennom analyse av utvalgte styringsdokumenter.

\begin{tabular}{l}
\hline Inkludering \\
\hline Salamancaerklæringen: "Regular schools with \\
this inclusive orientation are the most effective \\
means of combating discriminatory attitudes, \\
creating welcoming communities, building \\
an inclusive society and achieving education for \\
all ..." (s. ix)
\end{tabular}

Overordnet del av læreplanen: «Skolen skal fremme demokratiske verdier og holdninger som motvekt mot fordommer og diskriminering. Skolen skal også skape respekt for at mennesker er forskjellige, og elevene skal lære å løse konflikter på en fredelig måte» (s. 8).

Meld. St. 28 (2015-2016): «Temaet demokrati og medborgerskap omfatter blant annet samhandling $i$ et flerkulturelt samfunn foreslått i NOU 2015: 8. Temaet er forankret i formålspragrafen som understreker at opplæringen skal fremme demokrati, og at elevene har rett til medbestemmelse» (s. 38)

NOU 2015: 2:

"Utvalget legger til grunn at fremming av et trygt psykososialt skolemiljø er avgjørende for å forhindre krenkelser. Utvalget er i tillegg opptatt av det forebyggende arbeidet mot krenkelser og hva som skal til for å håndtere krenkelser når de skjer» (s. 31)

\footnotetext{
Salamancaerklæringen:

"Successful school management depends upon the active and creative involvement of teachers and staff, and the development of effective co-operation and team work to meet the needs of students" (s. 24)

Meld. St. 28 (2015-2016): "Skole og lærebedrift skal gi elevene og lærlingene lyst og evne til å lære mer og oppdage mer, både i videre utdanning og $i$ arbeidslivet. Kreativitet er en viktig egenskap både for den enkelte elev og for det norske samfunnet" (s. 24)
}

\section{NOU 2015: 2:}

"Utvalget vil derfor anbefale at begrepet sosial og emosjonell kompetanse brukes i skolens arbeid med det psykososiale skolemiljøet. Mer spesifikt mener utvalget at dette handler om utholdenhet, selvkontroll, selvregulering, selvtillit, nysgjerrighet, kreativitet, evne til å stole på omverdenen og til å bidra i samfunnet, evne til å takle motgang, evne til å håndtere følelser, empati og samarbeidsevner (s. 170)

\section{Kreativitet}

Mulighetsrom

Fredskultur

Estetisk tilnærming til læring

Road map 06: “... encouraging emotional development, can bring about a better balance between cognitive and emotional development and thereby contribute to support a culture of peace"

$$
\text { (s. 5) }
$$

Seoul agenda 10: "Apply arts education to foster democracy and peace in communities and to support reconstruction in postconflict societies" (s. 10) 


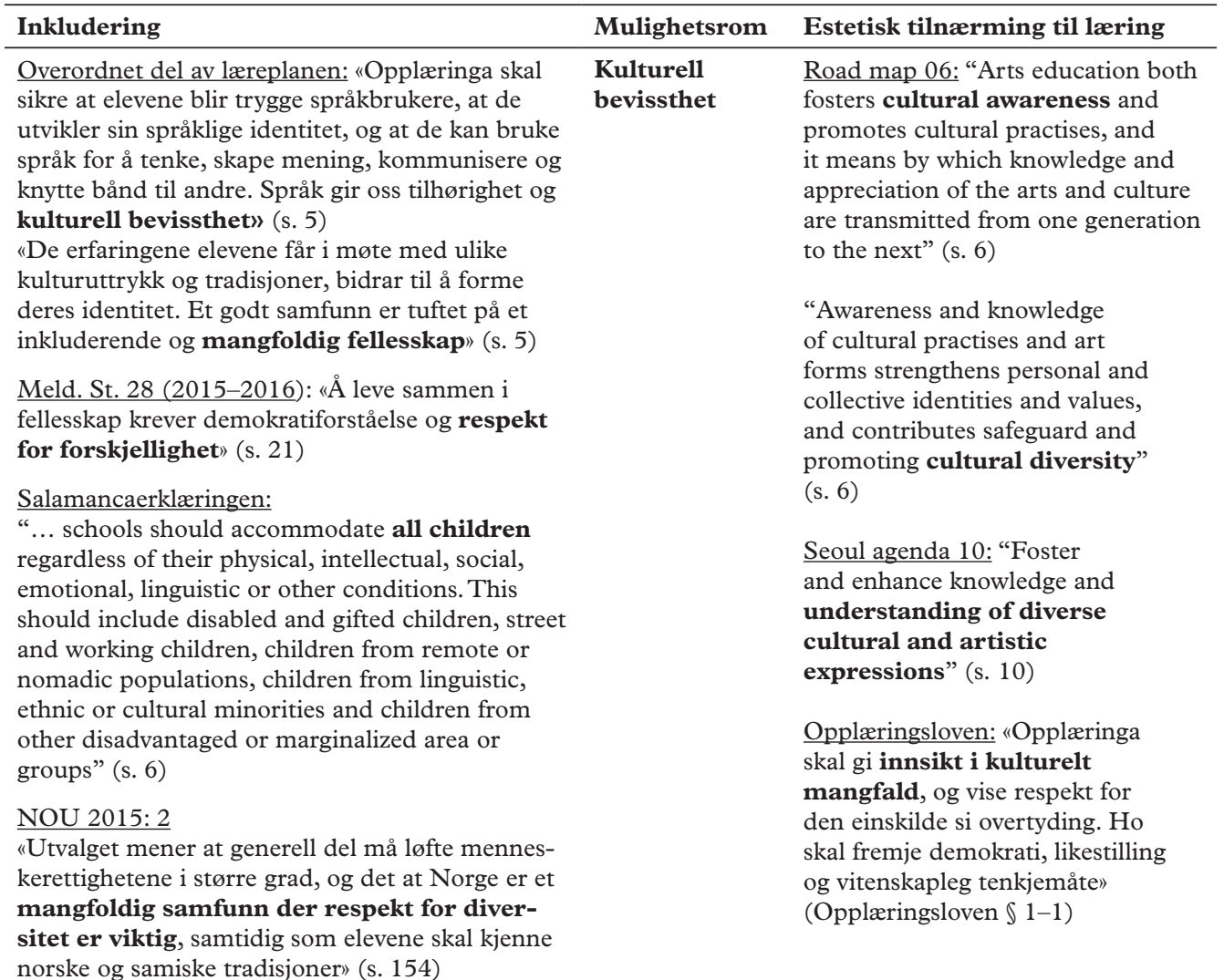
norske og samiske tradisjoner» (s. 154)

Overordnet del av læreplanen: «Skolen skal respektere og dyrke fram forskjellige måter å utforske og skape på. Elevene skal lære og utvikle seg gjennom sansing og tekning, estetiske uttrykksformer og praktiske aktiviteter» (s. 7)

Salamancaerklæringen: The content of education should be geared to high standards and the needs of individuals with a view to enabling them to participate fully in development (s. 22)

Meld. St. 28 (2015-2016): "Utvikling av grunnleggende ferdigheter er imidlertid ikke tilstrekkelig for å utøve rollen som demokratisk medborger. Elevene må også tilegne seg kunnskap om demokrati og samfunnsdeltagelse og få øve på, erfare og praktisere demokratiske prosesser $\mathbf{i}$ praksis" (s. 38)

NOU 2015: 2

«Når klasseledelsen fungerer, vil klassen være preget av lite konflikter og negativ atferd, smidige overganger mellom aktiviteter, adekvate uttrykk for følelser, kommunikasjon preget av respekt, problemløsning, vekt på engasjement i læringsaktivitetene, samt støtte og responser tilpasset elevenes behov» (s. 122)

\section{Følelsesmessig} engasjement
Road map 06: "Without an emotional involvement, any action, idea or decision would be based purely on rational terms." (s. 5)

Opplæringsloven: «Elevane skal utvikle kunnskap, dugleik og holdningar for å kunne meistre liva sine og for å kunne delta $\mathrm{i}$ arbeid og fellesskap i samfunnet. Dei skal få utfalde skaparglede, engasjement og utforskartrang." (Opplæringsloven \ 1-1) 
Tabell 2. (forts.)

\begin{tabular}{lll}
\hline Inkludering & Mulighetsrom & Estetisk tilnærming til læring \\
\hline Overordnet del av læreplanen: «Skolen skal & Likeverdighet & $\begin{array}{l}\text { Road map 06: "Everyone, as a } \\
\text { member of society ... is entitled to } \\
\text { ta hensyn til mangfoldet av elever og legge til }\end{array}$ \\
$\begin{array}{l}\text { rette for at alle får oppleve tilhørighet i skole og } \\
\text { samfunn. Vi kan alle oppleve at vi skiller oss ut og } \\
\text { kjenne oss annerledes. Derfor er vi avhengig av at } \\
\text { ulikheter anerkjennes og verdsettes» (s. 4) }\end{array}$ & $\begin{array}{l}\text { and cultural rights indispensable } \\
\text { for his dignity and the free } \\
\text { development of his personality” } \\
\text { (s. 4) }\end{array}$ \\
Salamancaerklæringen: & &
\end{tabular}

"Inclusion and partipicipation are essential to human dignity and to the enjoyment and exercise of human rights" (s. 11)

Meld. St. 28 (2015-2016): "Barn og unge har rett til å bli møtt med tillit og respekt, og har rett til medvirkning. De skal delta i det sosiale fellesskapet som skolen er, preget av: respekt for den enkelte, likeverd, likestilling, ytringsfrihet, solidaritet og toleranse" (s. 6)

NOU 2015: 2

«Utvalget forventer at generell del tydelig løfter frem inkludering og sosial tilhørighet. Utvalget forventer også at alle elevers likeverd og like muligheter markeres tydelig i generell del» (s. 154)

Salamancaerklæringen: "A change in social perspective is imperative. For far too long, problems of people with disabilities have been compounded by a disabling society that has focused upon their impairments rather than their potential" (s. 7)

Meld. St. 28 (2015-2016): "For at elevene skal tilegne seg varig kunnskap og forståelse må lærerplanene være mer konsentrert om det viktigste elevene skal lære. Skolefagene skal derfor videreutvikles slik at det legges enda bedre til rette for elevenes dybdelæring og grunnleggende kompetanse i fagene» (s. 7)

NOU 2015: 2:

"sosiale og emosjonelle kompetanser er noe som kan utvikles og læres gjennom hele livet, og derfor ikke er fastlåste trekk hos elevene. For eksempel er elevenes motivasjon noe som kan påvirkes og utvikles» (s. 126)

\section{Utvikling}

Road map 06: "Education shall be directed to the full development of the human personality and to the strengthening of respect for human rights and fundamental freedoms" (s. 4)

Seoul Agenda: "Enhance synergy between the different aspects of development (creative, cognitive, emotional, aesthetic and social)" (s. 3)

Opplæringsloven: «Skolen og læringsbedrifta skal møte elevane og lærlingane med tillit, respekt og krav og gi dei utfordringar som fremjar danning og lærelyst." (Opplæringsloven \ 1-1)

Overordnet del av læreplanen: «I et større perspektiv er skapende læringsprosesser også en forutsetning for elevenes danning og identitetsutvikling» (s. 7) 